\title{
Rapidly growing traumatic cerebral aneurysm with early subarachnoid hemorrhage
}

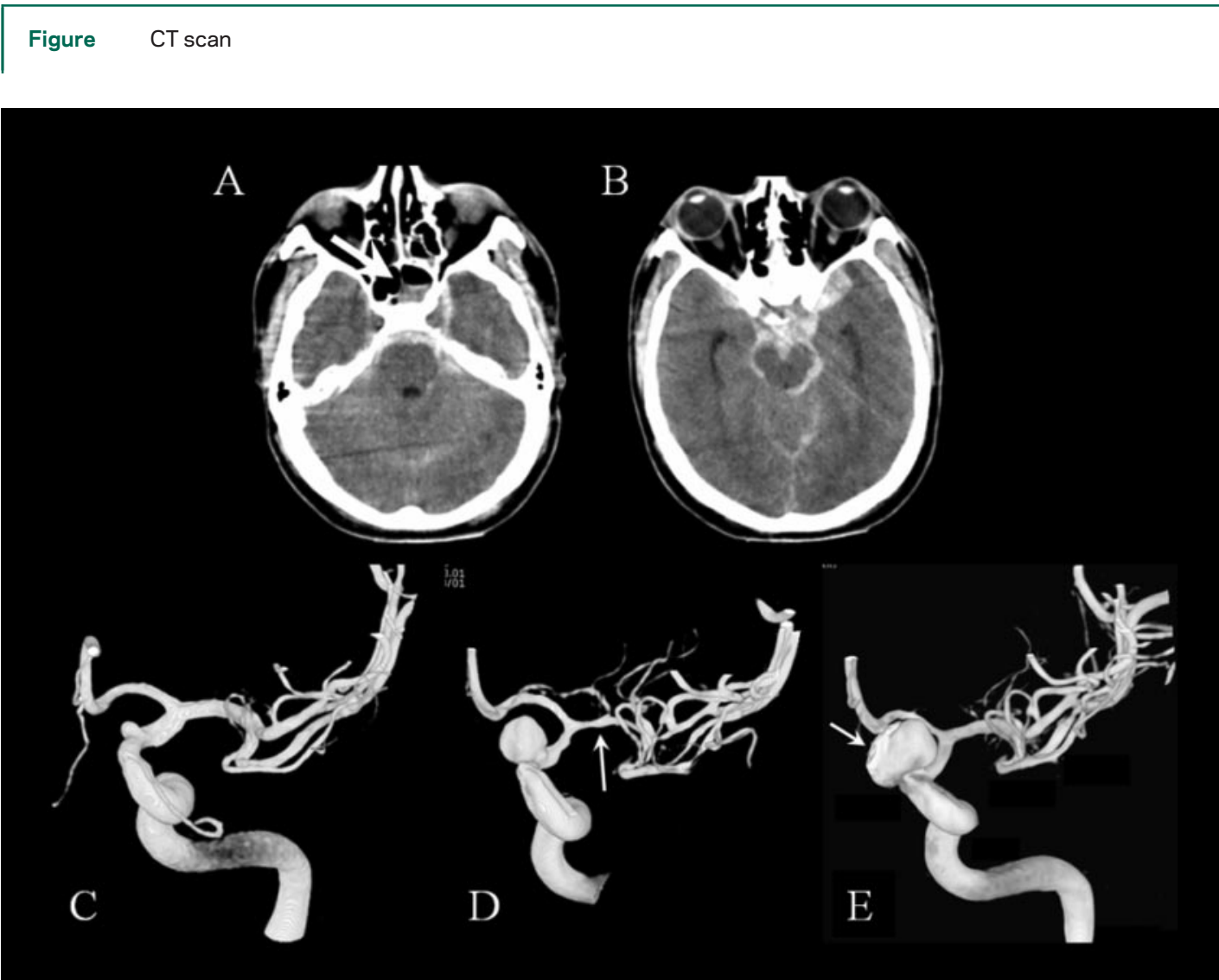

CT scan showed subarachnoidal blood in basal cisterns ( $A$ and B) and blood in sphenoid sinus (arrow). Initial angiogram showed small supraclinoidal aneurysm (C). One week later growth of the aneurysm (D) with vasospasm (arrow) was noted. Partial reopening of the aneurysm occurred 2 weeks after first coiling with displaced coil mesh (arrow).

A 40-year-old man riding a scooter was hit by a car. CT scan showed subarachnoidal blood in the basal cisterns and a skull base fracture (figure, A and B). Angiography revealed a 2-mm supraclinoid aneurysm (figure, C). Ambiguity about its relevance made us decide to wait. One week later the aneurysm had grown to $10 \mathrm{~mm}$ (figure, D) and it was coiled. However, 2 weeks later the aneurysm had enlarged again with partial reopening (figure, E) and additional coils were inserted.

Traumatic intracranial aneurysms are rare ${ }^{1}$ and rupture typically after a free interval. In our patient rupture must have occurred within the first hour.

D.Q. Ngo, MD, Willem Jan van Rooij, MD, PhD, Cees Tijssen, MD, PhD, Tilburg, the Netherlands Disclosure: The authors report no conflicts of interest.

Address correspondence and reprint requests to Dr. D.Q. Ngo, Department of Neurology, St Elisabeth Hospital, Tillurg, Hilvarenbeekseweg60, Tilburg, the Netherlands; d.ngo@elisabeth.nl.

1. Larson PS, Reisner A, Morassutti DJ, Abdulhadi B, Harpring JE. Traumatic intracranial aneurysms. Neurosurg Focus 2000;8:e4. 


\section{Neurology}

\section{Rapidly growing traumatic cerebral aneurysm with early subarachnoid hemorrhage}

D. Q. Ngo, Willem Jan van Rooij and Cees Tijssen

Neurology 2008;70;490

DOI 10.1212/01.wnl.0000299089.07740.a8

This information is current as of February 4, 2008

\section{Updated Information \&} Services

References

Subspecialty Collections

Permissions \& Licensing

Reprints including high resolution figures, can be found at: http://n.neurology.org/content/70/6/490.full

This article cites 1 articles, 0 of which you can access for free at: http://n.neurology.org/content/70/6/490.full\#ref-list-1

This article, along with others on similar topics, appears in the following collection(s):

Brain trauma

http://n.neurology.org/cgi/collection/brain_trauma

CT

http://n.neurology.org/cgi/collection/ct

Subarachnoid hemorrhage

http://n.neurology.org/cgi/collection/subarachnoid_hemorrhage

Information about reproducing this article in parts (figures,tables) or in its entirety can be found online at:

http://www.neurology.org/about/about_the_journal\#permissions

Information about ordering reprints can be found online:

http://n.neurology.org/subscribers/advertise

Neurology ${ }^{\circledR}$ is the official journal of the American Academy of Neurology. Published continuously since 1951, it is now a weekly with 48 issues per year. Copyright . All rights reserved. Print ISSN: 0028-3878. Online ISSN: 1526-632X.

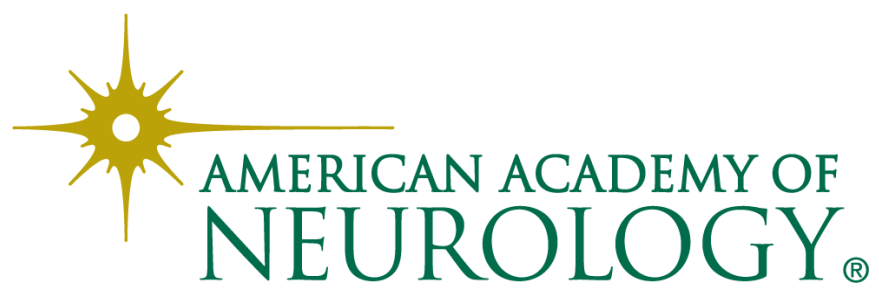

